NEWS

\title{
Stem-cell work thrown into limbo
}

\section{US district-court ruling suspends federal funding for research involving human embryonic stem cells.}

Candace Kerr was working late on 23 August when a postdoc sent her the link to a CNN story in an e-mail entitled: "Bad news for stem cell researchers." Kerr, a stem-cell scientist at Johns Hopkins University in Baltimore, Maryland, says that as her eyes flew down the screen, she thought: "This can't be real. This can't be right." Earlier that day, in Washington DC, a district-court judge had put a temporary stop on government funding for research involving human embryonic stem cells, pending resolution of a suit that is seeking to make the hold permanent (see 'The legalese behind the funding freeze').

"I was devastated," Kerr says. "It was a huge blow to the research I have spent so much time working on."

She summoned enough

"This ruling does greater harm to human embryonicstem-cell researchers than any policy ever enacted."

Even grants such as Kerr's that use stem-cell lines that were eligible for funding during the George W. Bush administration are not exempt: the Department of Justice read the injunction to apply to them too, Collins said.

For Kerr, there is little but bad news in Collins's message. In the short term, it means she can unfreeze her cells - the government's interpretation of the injunction allows researchers to spend any grant money already in hand. For Kerr, that amounts to about $\$ 100,000$ left of an existing two-year award for work aiming to identify factors that regulate pluripotency in embryonic stem cells. Once that money runs out next year, however, the ruling will prevent her from applying for more. And it could presence of mind to e-mail her lab technician, asking her to freeze 20 plates of human embryonic stem cells first thing in the morning. They were part of an experiment funded by the National Institutes of Health (NIH). Then, recalls Kerr, "I went home and stared at the walls and thought: 'What am I going to do next? What is going to sustain me for my job in the future?"”

Kerr is one of hundreds of researchers whose $\mathrm{NIH}$-supported work has been thrown into legal limbo and financial jeopardy by the ruling. The day after the injunction, NIH director Francis Collins affirmed that all new proposals for research on human embryonic stem cells more than 60 in total - had been pulled from peer review. Funding has also been suspended for existing multi-year projects by universitybased researchers, beginning with 22 projects, worth a total of US\$54 million, that were set to receive their next chunk of money this month. get worse: On 30 August, scientists working at the NIH campus in Bethesda, Maryland, were told to immediately shut down all experiments involving human embryonic stem cells. Uncertainty around the correct legal interpretation of the injunction means that 2010 money already in the hands of 199 grantees may still be in jeopardy.

"Even if the injunction is reversed in a couple of weeks, the impact will be in months and years," because of the disruption to NIH review cycles, says Linzhao Cheng, like Kerr, a stemcell scientist at the Institute for Cell Engineering at Johns Hopkins. Cheng estimates that $40 \%$ of his lab's funding, provided by two NIH grants, has been stopped by the injunction.

Still, he counts himself lucky, because he has generous support from the state of Maryland to fall back on - and because just one week before the injunction he received the second year's worth of monies for an NIH grant. For

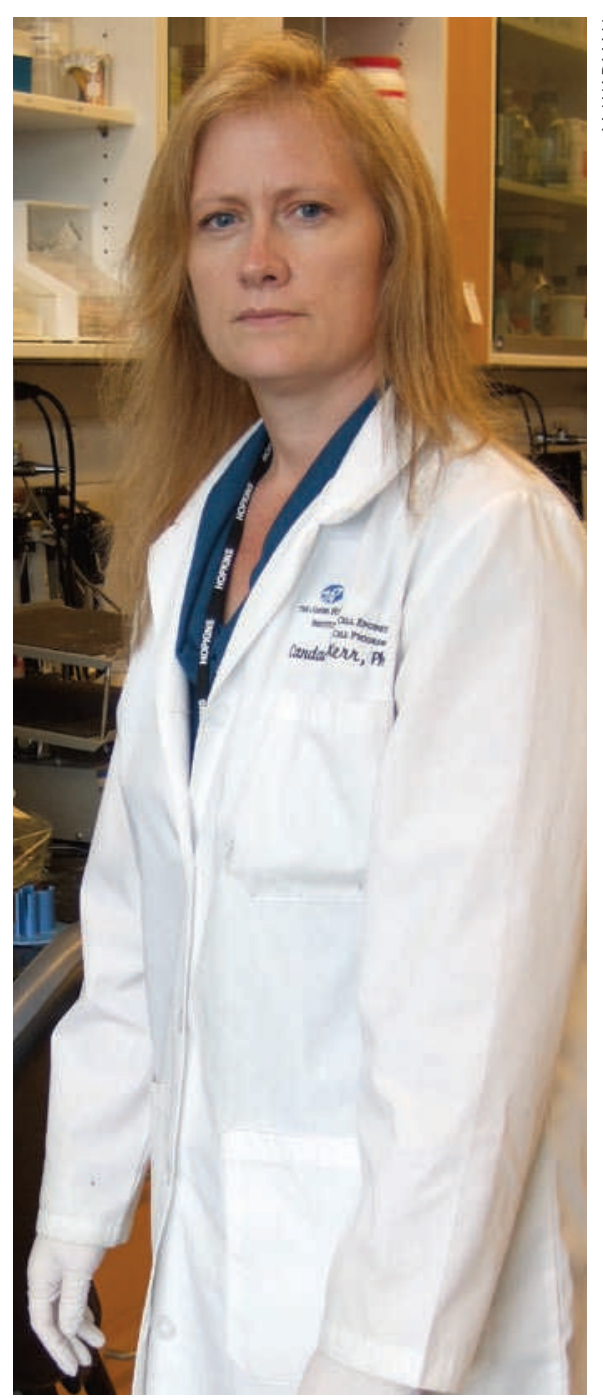

Candace Kerr's work relies on federal funding, and her plans are up in the air in the wake of the ruling.

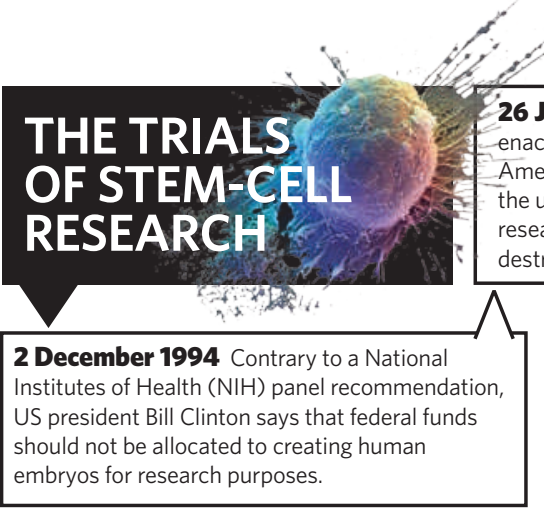

26 January 1996 Congress enacts the Dickey-Wicker Amendment, which prohibits the use of federal funds for research involving creation or destruction of human embryos.
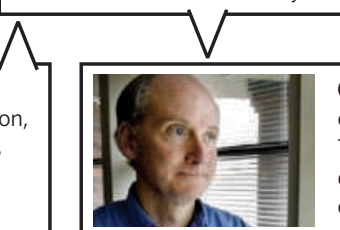

6 November 1998 University of Wisconsin biologist James Thomson publishes the first derivation of a human embryonic-stem-cell line.
15 January 1999 Department of Health and Human Services (HHS) lawyer Harriet

Rabb argues that human embryonic stem cells are not, per se, embryos. This forms the basis for approval of federal funding for embryonicstem-cell research, skirting Dickey-Wicker.

רives

19 July 2006 Bush uses the first veto of his presidency to reject a law that would have allowed funding for research on stem cells derived from donated embryos unused during fertility treatment.
9 August 2001 President George W. Bush issues an order restricting funding to human embryonic-stem-cell lines already derived.

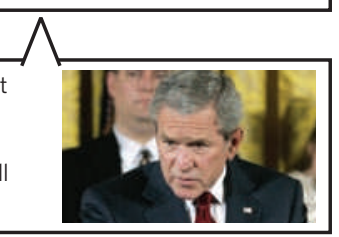


Kerr, an assistant professor striving to win tenure, the situation is much less certain. Although she gets modest Maryland state funding, it is not at all clear how she will be able to keep operating if she cannot apply for NIH grants. Last June, she submitted three proposals for projects, including one that would have used neural support cells derived from embryonic stem cells to attempt to treat spinal-cord injury in rats. All three are among the projects pulled from peer review. And with the injunction preventing her from applying for further funding on her current work, Kerr's plans are in limbo. A protégé of John Gearhart, one of the first scientists to isolate the cells, Kerr has spent the past seven years building expertise in human embryonic stem cells. To try to switch specialities and begin competing with much more experienced investigators in other areas would be "a real crusher", she says.

Well established researchers are feeling just as bleak. "It's like making a sculpture and then seeing it destroyed in front of you," says Ali Brivanlou, who works with stem cells at the Rockefeller University in New York.

Cheng worries most about persuading younger scientists to join a field beset with political uncertainties. "Why take the risk to work on embryonic stem cells that may not be fundable?" he asks.

The sense of shock seemed almost univer立 sal among US scientists last week. “This ruling does greater harm to human embryonic-stemcell researchers than any policy ever enacted," says Sean Morrison, director of the Center for Stem Cell Biology at the University of Michigan in Ann Arbor.

Collins echoed that assessment when he spoke to reporters after the injunction was issued. "This goes beyond politics," he said, pointing out that stem-cell research holds the promise of effective treatments for an array of diseases that urgently need them. "This decision potentially places all of that in jeopardy," he said.

Meredith Wadman

\section{The legalese behind the funding freeze}

The injunction, granted by Chief Judge Royce Lamberth of the US District Court for the District of Columbia, is the latest twist in a political and legal tug of war that predates the first derived human embryonic-stem-cell lines (see 'The trials of stem-cell research').

The ruling relates to two researchers who specialize in adult stem cells: James Sherley of the Boston Biomedical Research Institute in Watertown, Massachusetts, and Theresa Deisher of AVM Biotechnology in Seattle, Washington. The two are the only remaining plaintiffs in a lawsuit launched against the government by a coalition of Christian groups.

The suit was brought, Sherley told Nature, because in setting up new guidelines in 2009, the National Institutes of Health (NIH) failed to "articulate any reasoned basis for funding human embryonic stem-cell research over scientifically superior and ethical alternatives". The suit has been allowed to proceed because Sherley and Deisher argue that such work increases funding competition for scientists working on adult stem cells.

Lamberth found that they are likely to succeed in winning their case, and are facing "irreparable injury" unless government support for human embryonic-stemcell research is suspended. His assessment of their probable success is based on the 1996 Dickey-Wicker Amendment, named after the congressmen who affixed it to budget legislation for the $\mathrm{NIH}$. The amendment prohibits federal funding of research involving the creation or destruction of human embryos. Over the years,

\section{SLICES OF A GROWING PIE}

$\mathrm{NIH}$ budget figures suggest that research involving all stem cells, including human adult and embryonic ones, has grown; a modest decline is projected for 2011, when economic stimulus funds run out.

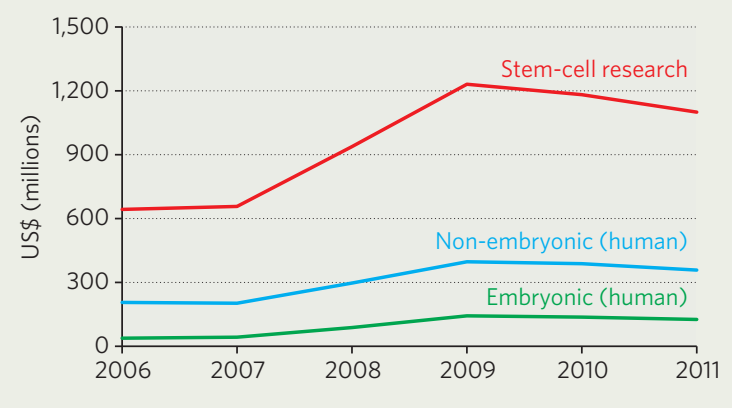

successive administrations have interpreted the word "research" in the amendment to refer only to those activities in which embryos are created or destroyed. However, Lamberth writes, the word refers "unambiguously" to the entire body of human embryonic-stem-cell research.

This sweeps away any distinction between deriving stem cell lines and working on lines that have already been derived - the current basis for federal funding. As to the question of competition, figures show that adultstem-cell research has not seen a drop in funding since embryonic stem cells began to draw from the NIH budget. In fact, funding for both has risen in parallel (see graph).

As Nature went to press, the Department of Justice was preparing to appeal the ruling. But even if successful, an appeal would only restore funding until the case goes to trial.

The surest way to end the battle would be the passage of legislation that would override the Dickey-Wicker amendment and enshrine the funding eligibility of embryonic-stem-cell research. Representative Diana DeGette (Democrat, Colorado), who in March reintroduced such a bill, says she will work to pass it when Congress resumes sitting on 13 September. Alla Katsnelson
9 March 2009 President Barack Obama issues an executive order overturning Bush's policy and charges the NIH with establishing guidelines for human embryonicstem-cell research.

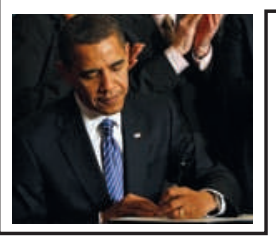

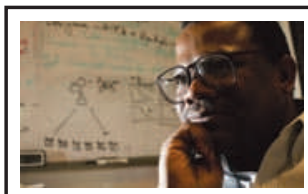

19 August 2009 Researchers James Sherley and Theresa Deisher are among a coalition of plaintiffs that files suit against the HSS and $\mathrm{NIH}$, arguing that the guidelines violate Dickey-Wicker.

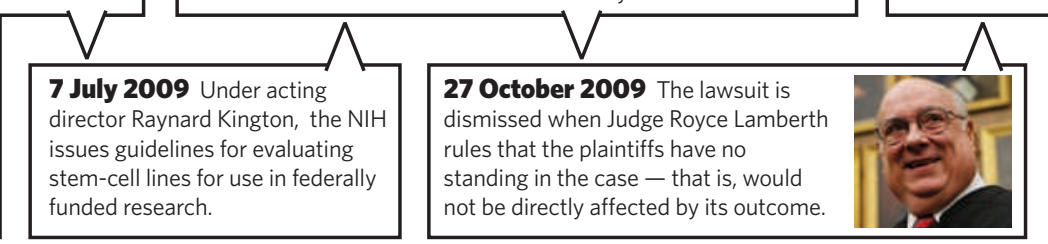

25 June 2010 Sherley and Deisher are granted standing, after appealing on the grounds that human embryonic-stem-cell research increases funding competition for their work on adult stem cells. 